\title{
Thermal Insulating Foams Produced From Glass Waste and Banana Leaves
}

\author{
Sabrina Arcaro ${ }^{a, b}$, Bianca Goulart de Oliveira Maia ${ }^{a, b} *$, Marcelo Tramontin Souza ${ }^{a, b}$, Francielly \\ Roussenq Cesconeto ${ }^{a, b}$, Laura Granados ${ }^{a}$, Antonio Pedro Novaes de Oliveira ${ }^{a, b}$ \\ ${ }^{a}$ Graduate Program in Materials Science and Engineering - PGMAT, Federal University of Santa \\ Catarina-UFSC, 88040-900, Florianópolis, SC, Brazil \\ ${ }^{b}$ Laboratory of Glass-Ceramic Materials - VITROCER, Federal University of Santa Catarina - UFSC, \\ 88040-900, Florianópolis, SC, Brazil
}

Received: October 10, 2015; Revised: May 2, 2016; Accepted: July 25, 2016

\begin{abstract}
In this work, compositions containing transparent glass bottles and banana leaves (desiccated and crushed), with different mass fractions (30-50\%), were prepared for obtaining cellular materials for thermal insulation purposes. The formulated and prepared compositions were uniaxially pressed (10 $\mathrm{MPa}$ ) and the compact powders fired between 700 and $850^{\circ} \mathrm{C}$ for $30 \mathrm{~min}$ in order to investigate the effect of the banana leaves on the formation of pores and on the thermal and mechanical properties of the processed glass foams. The results indicated that the obtained glass foams with porosities between 58.5 and $87.5 \%$, compressive strength ranging between 1.17 and $3.50 \mathrm{MPa}$ and thermal conductivity ranging between 0.06 and $0.15 \mathrm{~W} / \mathrm{mK}$, are potential candidates to work as thermal insulators with appropriate properties for a specific application.
\end{abstract}

Keywords: Cellular materials, wastes, glass foams, banana leaves

\section{Introduction}

Several different materials can be used for the manufacture of porous ceramics such as alumina, mullite, silicon carbide, zirconia and hydroxyapatite. However, recent studies have shown numerous advantages and possibilities for the use of discarded glasses to obtain glass foams ${ }^{1-3}$.

The use of glass foams is viable in applications involving temperatures lower than $500{ }^{\circ} \mathrm{C}$, for example in thermal insulation systems used in building such as panels, blocks, roofs, fireplaces, grills, among others ${ }^{1}$. These materials are also characterized by high porosity ( $>60 \%$ vol.) which can be opened, closed or mixed. The pore size, according to International Union of Pure and Applied Chemistry (IUPAC) ${ }^{2}$ can be classified as micro $(<2 \mathrm{~nm})$, meso $(2-50 \mathrm{~nm})$ or macropores $(>50 \mathrm{~nm})$. The distribution and amount of pores determine specific properties, such as low density and thermal conductivity, high surface area, permeability and chemical and thermal stability ${ }^{1,4,5}$. Furthermore, glass foams have mechanical strength and chemical and thermal stabilities greater than the polymeric foams typically employed in such cases ${ }^{1,6,7}$.

Several techniques or methods for producing porous ceramics are used and the process steps generally consist in preparing a suspension of a ceramic powder, forming and heat treatment (firing). Among the best known forming methods the replication method, gelcasting, foaming and incorporation of porogenic agents (pore formers) are highlighted ${ }^{1,8}$. Due to its simplicity, one of the techniques widely used for the production of glass foams, is the addition of a foaming agent to the powdered glass, followed by its removal in the

\footnotetext{
* e-mail: bianca.engenharia@gmail.com
}

heat treatment step (firing) to form a cellular structure 6, 7. The foaming agents can be synthetic (polymer) or natural (mineral and vegetable residues) $)^{7,9}$.

The natural residues show different constituents such as cellulose, hemicellulose and lignin, which open many value adding opportunities and can be a low cost alternative for use as foaming agents. Significant plant residues in tropical regions comes from banana cultivation, as banana leaves and pseudostem ${ }^{10}$. Banana is one of the most consumed fruits in the world and it is commercially grown in about 120 countries. Currently, Brazil is the second largest producer (preceded by India) and is responsible for $7.5 \%$ of world production. Further, for every ton of bananas produced approximately $3,000 \mathrm{~kg}$ of pseudostem, $160 \mathrm{~kg}$ of stems, $480 \mathrm{~kg}$ of leaves and $440 \mathrm{~kg}$ of skins are generated ${ }^{11}$.

The glass used in the manufacture of glass foams can, however, also be glass from the disposal. The recycling and the use of glass can contributes to the national energy matrix through the large amount of energy savings since to produce $1 \mathrm{~kg}$ of new glass $4500 \mathrm{~kJ}$ are needed, while to produce 1 $\mathrm{kg}$ of recycled glass $500 \mathrm{~kJ}$ only are needed ${ }^{12,13}$. In order to reduce production costs and get raw materials, several modifications have been applied to the processing techniques and starting materials ${ }^{6}$. In addition, glass foams represent an interesting destination for glass wastes and vegetables from an economic and environmental point of view.

In this context, the objective of this work was to produce cellular materials (glass foams) from glass bottles and banana leaves in different mass fractions to be used as thermal insulators. 


\section{Materials and Methods}

In this study transparent glass bottles, TGB (soda-lime type) and banana leaves (BL) were used as raw materials. The selected glass bottles were washed and dried at $110^{\circ} \mathrm{C}$ for $2 \mathrm{~h}$ in a laboratory dryer $\left(\mathrm{SP} \mathrm{LABOR}^{\circledR}\right)$. In a subsequent step, the glass bottles were crushed in a crusher hammer (Servitech, CT058), and the resulting product milled for $30 \mathrm{~min}$ in a fast mill (Servitech, CT-242) constituted by a porcelain jar containing alumina balls and water such that powders with particle sizes lower than $44 \mu \mathrm{m}$ (325 Mesh) were obtained. The average particle size distribution $\left(\mathrm{d}_{50}=6 \mu \mathrm{m}\right)$ of the resultant material was determined using a laser scattering particle size analyzer (Master Sizer 2000, Malvern). The chemical characterization of the obtained glass powders was performed by X-ray fluorescence spectroscopy (XRF, Philips PW 2400).

Samples of dried banana leaves were obtained directly from banana trees but only the dried leaves were collected. The pseudostem was obtained only from plants that had been cut for obtaining fruit and were decomposing in the soil. The pseudostem, since it has a high humidity content, was pressed in a hydraulic press to remove the largest liquid fraction and then it was dried in a forced ventilation muffle at $60^{\circ} \mathrm{C}$ for $24 \mathrm{~h}$. Both samples were milled so that a powder with an average particle size of $2.5 \mathrm{~mm}$ was obtained. The obtained powder samples were characterized by proximate chemical analysis, following procedures described in ASTM E1871-82 (2006) for moisture, ASTM E872-82 (2006) for volatile materials, ASTM E1755-01 (2007) for ash and ASTM E1756-08 (2008) for total solids and fixed carbon; elemental chemical analysis (carbon, nitrogen and hydrogen) by elemental analyzer (Perkin-Elmer CHN 2400) and sulfur by atomic emission spectrometer with inductively coupled plasma (Spectro Ciros CCD). The samples of both wastes were dried at $110^{\circ} \mathrm{C}$ for $2 \mathrm{~h}$ in a muffle and then mixed (dry mixing in a ball mill for $5 \mathrm{~min}$ ) with different proportions of TGB (50-70 wt \%) and BL (30-50 wt $\%$ ) and with addition of $5 \%$ water. The prepared mixtures were at a later stage, uniaxially pressed (10 $\mathrm{MPa})$ in a steel matrix by means of a hydraulic press (Bovenau P10 ST). The obtained powder compacts in the form of discs $(10 \times 6 \mathrm{~mm})$ were dried at $110^{\circ} \mathrm{C}$ for $2 \mathrm{~h}$.

The thermal behaviour during firing of raw materials and prepared compositions was studied by means of an optical dilatometer (Expert System Solution Misura ODHT) and by a thermal analyser equipment (TA Instruments, SDT Q600 - Simultaneous TGA-DSC) at a heating rate of $10^{\circ} \mathrm{C} /$ min with a flow of synthetic air of $10 \mathrm{~cm}^{3} / \mathrm{min}$.

Based on the thermal analyses, green compacts were heated in a muffle furnace (Jung J200) up to $600{ }^{\circ} \mathrm{C}$ at 0.5 ${ }^{\circ} \mathrm{C} / \mathrm{min}$ with a holding time of $30 \mathrm{~min}$ (first step) and then heated at different temperatures $\left(700,800\right.$ e $\left.850{ }^{\circ} \mathrm{C}\right)$ for 30 min at $10^{\circ} \mathrm{C} / \mathrm{min}$ (second step) and finally cooled to room temperature, $\sim 25^{\circ} \mathrm{C}$ (third step).
To identify the crystalline phases formed during firing, diffractometric analysis were carried out in a X-ray diffractometer (Philips, model X'Pert, The Netherlands). In this case, powdered samples fired in the $700-850{ }^{\circ} \mathrm{C}$ temperature range were prepared. A glass sample (unheattreated one) was also prepared and subjected XRD analysis.

The true densities $\left(\rho_{t}\right)$ of powdered samples were determined by using a helium pycnometer (AccuPyc 1340, Micromeritics, USA). The apparent densities $\left(\rho_{a}\right)$ of fired samples were determined by relating their geometrical measurements, obtained using a caliper (Mitotoyo, accuracy $\pm 0.01 \mathrm{~mm}$ ), and their masses (Shimadzu AX200 at 0.001 g). The relative densities $\left(\rho_{r}\right)$ were determined, relating the apparent densities and the true densities of the samples. From measurements of geometrical and true densities (same procedures used for powder compacts), the porosities ( $\varepsilon$ ) of fired glass foams were calculated according to equation 1 .

$$
\varepsilon(\%)=\left(1-\frac{\rho_{a}}{\rho_{t}}\right) \times 100
$$

The microstructure of pores could be seen from images of fractured surfaces of fired samples, obtained in a scanning electron microscope, SEM (Philips, XL-30).

To determine the mechanical strength of the produced glass foams, compression tests (Stable Micro Systems TA. XT Plus Texture Analyzer - cell load of $500 \mathrm{~N})$ at $\sim 25^{\circ} \mathrm{C}$ were performed on 5 cylindrical samples (10 $\mathrm{mm}$ diameter) with a loading speed of $1 \mathrm{~mm} / \mathrm{min}$.

The thermal conductivity of the obtained materials was determined by a TCi Thermal Conductivity C-THERM TECHNOLOGIES on disk-shaped samples of $30 \mathrm{~mm}$ diameter and $8 \mathrm{~mm}$ thick.

\section{Results and Discussion}

Table 1 shows the chemical composition of the transparent glass bottle (TGB) used in this work. It can be verified the predominant presence of $\mathrm{SiO}_{2}, \mathrm{Na}_{2} \mathrm{O}$ and $\mathrm{CaO}$ in amounts typically found in soda-lime-silica glasses.

Figure 1 shows linear shrinkage and differential scanning calorimetric (DSC) curves related to the TGB. As observed, combining the techniques of dilatometry and differential scanning calorimetry (DSC), it can follow the thermal behavior of the TGB. It is found that there is a discontinuity in the baseline around $520^{\circ} \mathrm{C}$, which is characteristic of the glass transition temperature $(\mathrm{Tg})^{14}$.

It is also observed in Figure 1, an endothermic peak at about $1000{ }^{\circ} \mathrm{C}$ which may be attributed to the melting $\left(\mathrm{T}_{\mathrm{m}}\right)$ of the glass (melting of the crystalline phases formed during the heating of the glass), which can be confirmed by observing the linear shrinkage curve and the images (in the same Figure) obtained during this thermal analysis. Moreover, according to X-ray diffractions (Figure 2), in fact, crystobalite, JCPDS 01.076-0939 (main crystalline 
Table 1: Chemical composition of the TGB obtained by XRF. L.O.I: loss on ignition.

\begin{tabular}{cccccccccc}
\hline \multicolumn{10}{c}{ Constitutive oxides (wt \%) } \\
\hline $\mathrm{SiO}_{2}$ & $\mathrm{Al}_{2} \mathrm{O}_{3}$ & $\mathrm{Fe}_{2} \mathrm{O}_{3}$ & $\mathrm{CaO}$ & $\mathrm{K}_{2} \mathrm{O}$ & $\mathrm{Na}_{2} \mathrm{O}$ & $\mathrm{P}_{2} \mathrm{O}_{5}$ & $\mathrm{TiO}_{2}$ & L.O.I \\
70.95 & 2.16 & 0.10 & 9.60 & 0.02 & 16.76 & 0.03 & 0.05 & 0.33 \\
\hline
\end{tabular}

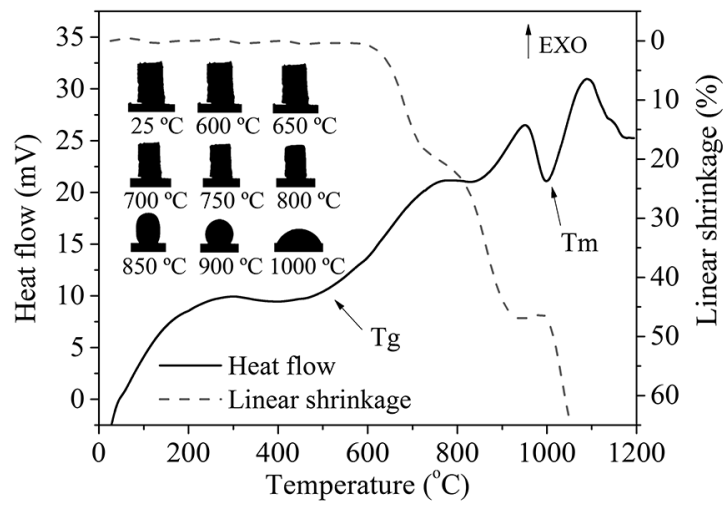

Figure 1: Linear shrinkage (also showing pictures of specimen tested in different temperatures) and DSC curves of the TGB.

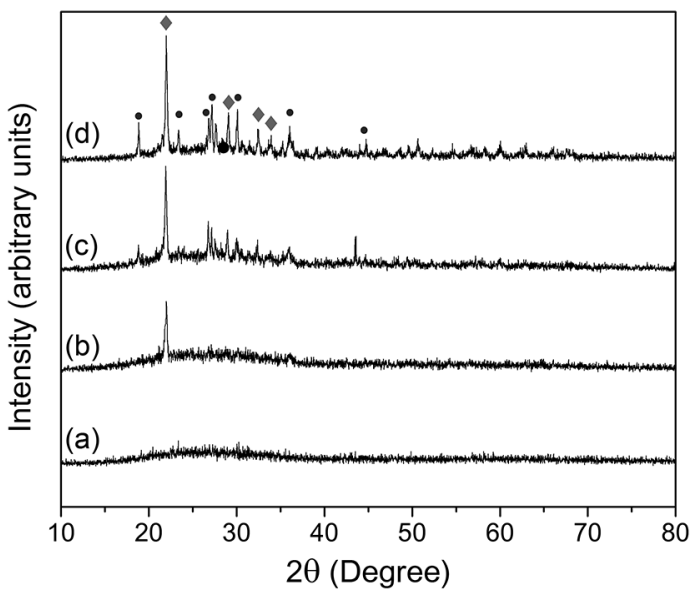

Figure 2: X-ray diffraction patterns of the glass sample (unheattreated one) (a) and after firing at $700(\mathrm{~b}), 800(\mathrm{c}), 850^{\circ} \mathrm{C} / 30 \mathrm{~min}(\mathrm{~d})$. - Cristobalyte (JCPDS 01.076-0939) • Calcium sodium silicate (JCPDS 00.023-0671)

phase) and calcium-sodium silicate, JCPDS 00.023-0671 toke place in the $700-850{ }^{\circ} \mathrm{C}$ temperature range (Figure 2 (b-d)) and from $800{ }^{\circ} \mathrm{C}$ (Figure 2 (c-d)), respectively. Thus, it clear, according to Figure 2 (a) for a glass sample (unheat-treated sample) that crystallization toke places in the studied temperature range explaining thus the observed (in Figure 1) melting temperature.

It is observed further from the linear shrinkage curve that around $600{ }^{\circ} \mathrm{C}$ begins the sintering processes of the glass powder. At $850^{\circ} \mathrm{C}$ the glass powder compacts start to lose their geometric shape, probably explained by the low glass viscosity with increasing temperature. At $900{ }^{\circ} \mathrm{C}$ the glass already has a ball-shape and at $1000^{\circ} \mathrm{C}$, it may realizes by dilatometry (in terms of shrinkage) and by DSC, that the glass melting $\left(\mathrm{T}_{\mathrm{m}}\right)$ occurred.

Table 2 shows the results of proximate elemental and chemical analysis of BL samples ${ }^{10}$.

The moisture of the BL used was approximately $8 \%$. The biomass moisture is an important factor since it interferes directly on other parameters such as the lower heating value, which decreases with increasing moisture content and thermal conductivity $^{10,15}$. The volatile solid contents indicate the presence of organic matter and represent lignocellulosic and carbon fractions present in the samples, and expresses the weight amount of the components of biomass which first are combusted ${ }^{15,16}$. The ashes represent $6.2 \%$ of the total. Studies indicate low ash concentration in biomass from 0.3 to $1 \%$, but in agricultural residues such as rice husks, ashes may represent $23 \%$ and less than $3 \%$ for sugar cane bagasse ${ }^{10,15,17}$. The carbon content found was $43.4 \%$.

Table 2: Proximate chemical and elemental analysis of banana leaf (BL) samples.

\begin{tabular}{lc}
\hline Parameters & Contents (wt\%) \\
\hline Moisture & $7.81 \pm 0.3$ \\
Volatile solids & $78.16 \pm 0.8$ \\
Fixed carbon & $15.59 \pm 0.4$ \\
Ashes & $6.2 \pm 0.4$ \\
Carbon & 43.28 \\
Hydrogen & 6.23 \\
Nitrogen & 0.98 \\
Sulfur & 0.49 \\
\hline
\end{tabular}

Figure 3 shows the weight loss, from thermogravimetry analysis (TGA), and differential scanning calorimetry (DSC) curves of the BL. The BL showed two stages of thermal degradation.

The first (a) from room temperature to about $150^{\circ} \mathrm{C}$, which is related to moisture loss from the sample, corresponding to a weight loss of $10.7 \%$ for the leaves. These values are close to those found by proximate analysis, presented earlier. In the second stage (b), between $150{ }^{\circ} \mathrm{C}$ and $580^{\circ} \mathrm{C}$, a largest weight loss attributed to volatile materials and degradation of hemicellulose (cellulose and lignin portion - constituents of the biomass) was registered, with mass losses for the leaves samples of $80.3 \%$. At this stage it is also possible to identify the ignition temperature of the biomass combustion process ${ }^{17}$.

The results indicate that $91 \%$ of $\mathrm{BL}$ decompose up to $580{ }^{\circ} \mathrm{C}$. Still according to Figure 2, the exothermic peaks 


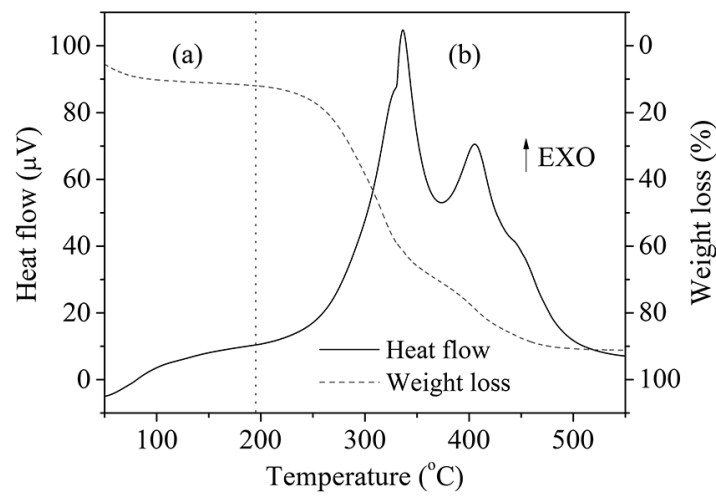

Figure 3: DSC/TGA curves of banana leaf samples.

correspond to thermal degradation of hemicellulose fractions stages, cellulose and lignin gradually. The greater release of energy in which occurs the degradation of volatiles was observed in the second event nearly at $400^{\circ} \mathrm{C}$. The thermal degradation of biomass products consist of moisture, volatiles and $\operatorname{ash}^{5}$. The volatiles are subdivided into gases, such as light hydrocarbons, carbon monoxide, carbon dioxide and tar. Yields depend on the temperature and heating rate ${ }^{17}$.

Based on the thermal behavior of the TGB and BL, it was defined the following firing cycle of the compacts constituted by TGB and BL: heating at $0.5^{\circ} \mathrm{C} / \mathrm{min}$ up to $600^{\circ} \mathrm{C}$ for 120 min to decomposition of $\mathrm{BL}$ and thus the release of $\mathrm{CO} /$ $\mathrm{CO}_{2}$ gases which are responsible for the formation of pores. This temperature $\left(600{ }^{\circ} \mathrm{C}\right)$ is near the glass transition $(\mathrm{Tg})$ and the TGB, despite being in a viscous state, still retains the cell structure caused by the decomposition of leaves. Subsequently, the temperature was increased to 700,800 , $850{ }^{\circ} \mathrm{C}$ at $10^{\circ} \mathrm{C} / \mathrm{min}$ to promote the sintering of the bodies and thus the trapping of gases released in the decomposition step of the banana leaves. Figures 4 show the effect of the firing temperature and BL content on the apparent density of the produced glass foams.

It can be seen from Figure 4 that the apparent densities ranged between 0.31 and $1.03 \mathrm{~g} / \mathrm{cm}^{3}$. Compositions with $50 \%$ added BL showed the lowest densities for all tested sintering temperatures.

Figure 5 shows the results of mechanical strength $\left(\sigma_{\mathrm{f}}\right)$ tests and porosity $(\varepsilon)$ of glass foams with additions of 30 , 40 and $50 \% \mathrm{BL}$, fired at 700,800 and $850{ }^{\circ} \mathrm{C}$ for $30 \mathrm{~min}$.

As can be seen, the porosity of the produced glass foams ranged from 58.5 to $87.5 \%$. As the firing temperature increases from 700 to $800^{\circ} \mathrm{C}$ the porosity remained practically constant. However, at $850^{\circ} \mathrm{C}$ there is a significant decrease in porosity for all studied compositions, in contrast to the apparent density, which is related to a decrease of the glass viscosity which was not sufficient to maintain the cell structure, since $850^{\circ} \mathrm{C}$ is very close to its melting temperature, as previously mentioned. The sharp decreases of the mechanical strength of the glass foams of all compositions with increasing firing

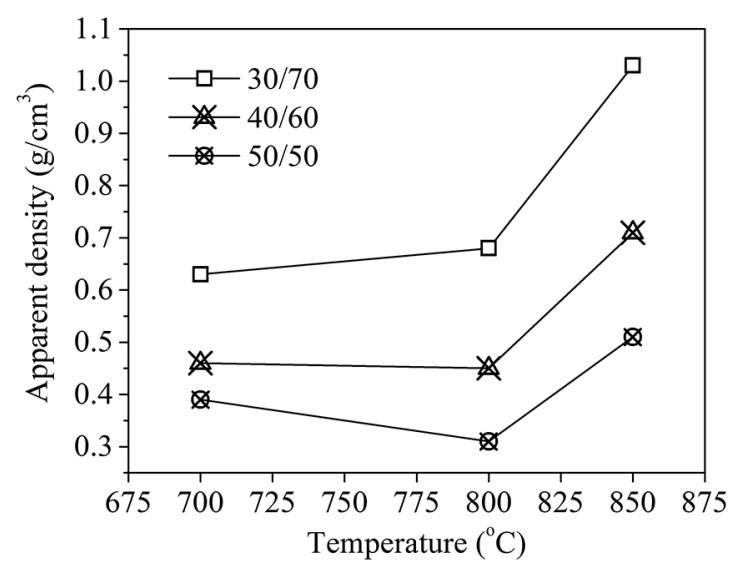

Figure 4: Effect of the firing temperature and BL content on the apparent density of the produced glass foams.

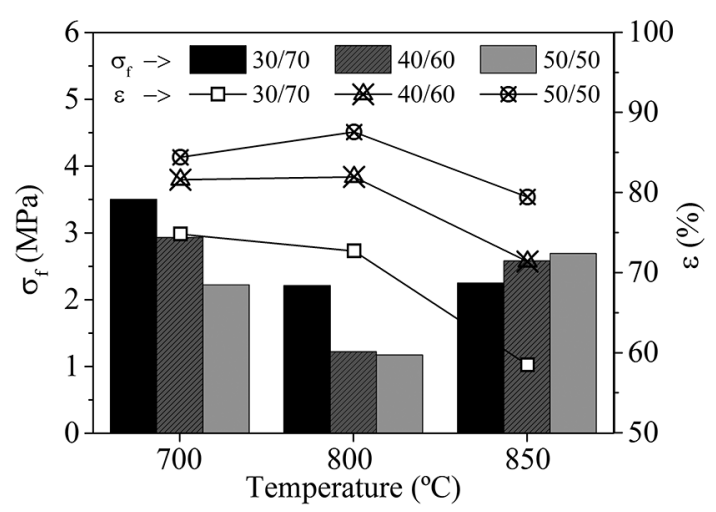

Figura 5: Effect of the firing temperature on the mechanical strength $\left(\sigma_{f}\right)$ and porosity $(\varepsilon)$ of the produced glass foams for different compositions (BL/TGB).

temperature, i.e., from 700 to $800{ }^{\circ} \mathrm{C}$ can be associated, probably, to the crystobalite formation as shown in the XRD (Figure 2) since it has a very high coefficient of thermal expansion which results in crack formation during cooling process. With the increment of temperature from 800 to $850{ }^{\circ} \mathrm{C}$, the mechanical strength increases due a porosity decreasing associated, probably, to a decreasing of the glass (TGB) viscosity, as previously mentioned, which causes the rupture of the pore's walls allowing the gases to escape (specially for samples containing high BL concentrations) resulting in a lower porosity (glass densification). The rupture of the pore's walls and so the escape of gases is a consequence of the high internal pressure which expand the porous in the low viscous glass. In fact, in the glass working range temperature, the viscosity $\left(10^{6.6}\right.$ to $\left.10^{3} \mathrm{~Pa} \cdot \mathrm{s}\right)$ is low enough, allowing the pressure of the produced gases from the decomposition of the foaming agent, expands the glass producing porosity which can be controlled depending on the selected temperature and holding time at temperature. This can explain why samples fired at $850{ }^{\circ} \mathrm{C}$ have a reverse mechanical strength behavior. However, even if porosity 
values are lower than those of samples fired at 700 and $800^{\circ} \mathrm{C}$, crystobalite volume (Figure 2) seems to be higher (higher peak intensity) than that observed at $800{ }^{\circ} \mathrm{C}$ but in particular than the sample fired at $700{ }^{\circ} \mathrm{C}$ for $30 \mathrm{~min}$. Thus, seems that crystobalite as porosity has an important influence on the mechanical strength.

Figure 6 shows the results of thermal conductivity of glass foams with additions of $30,40,50 \%$ BL fired at 700 , $800,850^{\circ} \mathrm{C}$ for $30 \mathrm{~min}$.

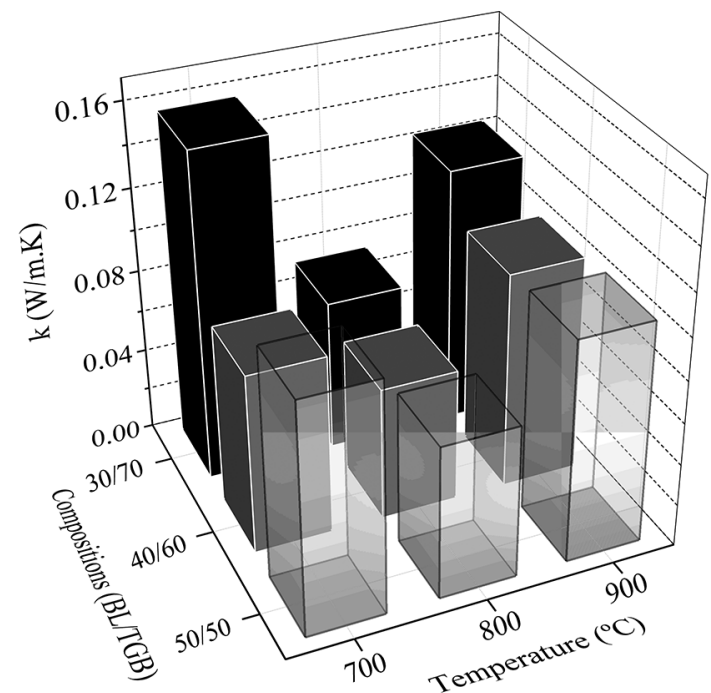

Figure 6: Thermal conductivity of glass foams with additions of $30,40,50 \%$ BL fired at $700,800,850^{\circ} \mathrm{C}$ for $30 \mathrm{~min}$, respectively.

It can be seen that the thermal conductivity of the produced glass foams decreases with increasing firing temperature ( 700 to $800{ }^{\circ} \mathrm{C}$ ). This is due to the contribution of a higher porosity which reduces the thermal conductivity, especially in cases where the pores are closed and no interconnected. With the increment of temperature from 800 to $850{ }^{\circ} \mathrm{C}$, it is found that the thermal conductivity increases due a porosity decreasing in good agreement with the literature ${ }^{1}$.

In fact, Figure 7 shows micrographs showing the mentioned before aspects.

As is known, in general, the porosity causes a decrease in the mechanical strength of the materials. Typically, the subjected foams have a mechanical (compressive strength) behavior characterized by three regimens, i.e., linear elastic, plateau and densification. Initially occurs the elastic deformation of the walls and/or struts of the glass foams. The plateau region, the second stage, begins when there is a sharp drop in the stress value which is associated with fracture of the material. This region presents large fluctuations of stress due to the successively breaking of struts which constitute the glass foam. In the third stage of the process, the stress increases due to densification of the glass foam?

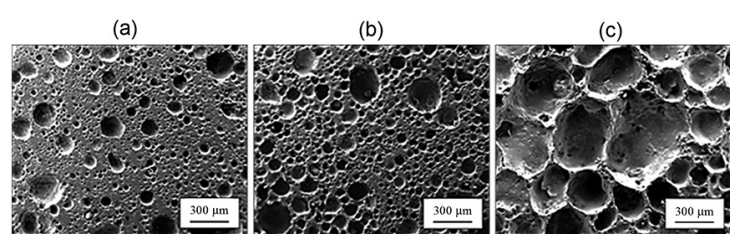

Figure 7: SEM micrographs of glass foams fired at $800{ }^{\circ} \mathrm{C}$ for 30 min. (a) $30 \%$, (b) $40 \%$, (c) $50 \%$ BL.

\section{Conclusions}

Based on the proposed objectives of this work, it is concluded that produced glass foams fired between 700 and $850{ }^{\circ} \mathrm{C}$ for $30 \mathrm{~min}$ and with porosities between 58.5 and $87.5 \%$ had compressive strength ranging between 1.17 and $3.50 \mathrm{MPa}$ and thermal conductivity ranging between 0.06 and $0.15 \mathrm{~W} / \mathrm{mK}$.

The dried banana leaves proved to be a vegetable residue with interesting properties for use as foaming agent, indicating new applications for this residue.

The values of the evaluated properties indicate that the obtained glass foams can be recommended as heat insulation panels which require an appropriate combination of thermal conductivity, porosity and mechanical strength.

\section{Acknowledgments}

The authors are grateful to FAPESC/CNPq (PRONEX T.O. N. 17431/2011-9) for funding this work.

\section{References}

1. Scheffler M, Colombo P, eds. Cellular Ceramics: Structure, Manufacturing, Properties and Applications. Weinheim: Wiley-VCH; 2005.

2. Rouquerol J, Avnir D, Fairbridge CW, Everett DH, Haynes JM, Pernicone N, et al. Recommendation for the characterization of porous solids. Pure and Applied Chemistry. 1994;66(8):1739-1758.

3. Zhu X, Jiang D, Tan S. Preparation of silicon carbide reticulated porous ceramics. Materials Science and Engineering: A. 2002;323(1-2):232-238.

4. Barg S, Soltmann C, Andrade M, Koch D, Grathwohl G. Cellular ceramics by direct foaming of emulsified ceramic powder suspensions. Journal of the American Ceramic Society. 2008;91(9):2823-2829.

5. Zeschky J, Goetz-Neunhoeffer F, Neubauer J, Jason Lo SH, Kummer B, Scheffler M, et al. Preceramic polymer derived cellular ceramics. Composites Science and Technology. 2003;63(16):2361-2370.

6. Bernardo E, Cedro R, Florean M, Hreglich S. Reutilization and stabilization of wastes by the production of glass foams. Ceramics International. 2007;33(6):963-968.

7. Gibson LJ, Ashby MF. Cellular Solids: Structure and Properties. $2^{\text {nd }}$ ed. New York: Cambridge University Press; 1999. 
8. Studart AR, Gonzenbach UT, Tervoort E, Gauckler LJ. Processing routes to macroporous ceramics: A review. Journal of the American Ceramic Society. 2006;89(6):1771-1789.

9. Sousa E, Rambo CR, Montedo ORK, Hotza D, Oliveira APN. Glass ceramics porous LZSA system using organic waste as pore-forming agent. Exacta. 2006;4(2):289-296 (in Portuguese).

10. Sellin N, Oliveira BG, Marangoni C, Souza O, Oliveira APN, Oliveira TMN. Use of banana culture waste to produce briquettes. Chemical Engineering Transactions. 2013;32:349-354.

11. Bello RH, Linzmeyer P, Franco CMB, Souza O, Sellin N, Medeiros SHW, et al. Pervaporation of ethanol produced from banana waste. Waste Management. 2014;34(8):1501-1509.

12. Alves OL, Gimenes IF, Mazalli IO. Vidros. Cadernos Temáticos - Química Nova na Escola - Novos Materiais. 2001;Edição Especial:9-20 (in Portuguese).
13. Scarinci G, Brusatin G, Barbieri L, Corradi A, Lancellotti I, Colombo P, et al. Vitrification of industrial and natural wastes with production of glass fibers. Journal of European Ceramic Society. 2000;20(14-15):2485-2490.

14. Padilha AF. Materiais de Engenharia: Microestrutura e Propriedades. São Paulo: Hemus; 2000 (in Portuguese).

15. Fernandes ERK, Marangoni C, Souza O, Sellin N. Thermochemical characterization of banana leaves as a potential energy source. Energy Conversion and Management. 2013;75:603-608.

16. García R, Pizzaro C, Lavín AG, Bueno JL. Characterization of Spanish biomass wastes for energy use. Bioresource Technology. 2012;103(1):249-258.

17. Demirbas A. Combustion characteristics of different biomass fuels. Progress in Energy and Combustion Science. 2004;30(2):219-230. 